\title{
RESEARCH PAPER \\ Quantitative differentiation between soil organic carbon and biochar carbon in Aridisol
}

\author{
Nelson Lara' ${ }^{1}$ Leonardo Figueroa' ${ }^{1}$ Fabiola Carvajal' ${ }^{1}$, Yubinza Zapata', \\ Camilo Urbina', and Hugo Escobar ${ }^{2}$ \\ 'Departamento de Química, Universidad de Tarapacá. Av. General Velásquez 1775, Arica, Chile. \\ ${ }^{2}$ Facultad de Ciencias Agronómicas, Universidad de Tarapacá, Valle de Azapa, Arica, Chile.
}

\begin{abstract}
N. Lara, L. Figueroa, F. Carvajal, Y. Zapata, C. Urbina, and H. Escobar. 2013. Quantitative differentiation between soil organic carbon and biochar carbon in Aridisol. Cien. Inv. Agr. 40(2): 387-395. To understand the effect of biochar, identify its presence and quantify its stability in soil, it is necessary to differentiate between the two main sources of carbon. These sources are resident soil organic matter and biochar, which is produced by burning organic matter under low oxygen concentration in a process known as pyrolysis. The present study employs solid-liquid extraction with an alkaline solution, the efficiency of which was improved by a reflux system and quantification using the modified Walkley-Black method, to distinguish the two carbon sources in samples of arid soils from the area surrounding the city of Arica, XV region of Chile. The mean annual precipitation of this area is less than $0.4 \mathrm{~mm}$, and its soils are characterized by high salinity, low organic matter content, high porosity and low bulk density. The values for total extracted organic carbon obtained using this method were very similar to those for the resident soil organic carbon, indicating that the technique extracts mostly resident soil organic carbon and not biochar carbon. Biochar carbon represented less than $6 \%$ of the total organic carbon extracted by the method. The results demonstrate that this method can quantitatively differentiate between resident total organic carbon and applied biochar carbon. The method thus represents a valuable alternative to the use of an elemental analyzer.
\end{abstract}

Key words: Alkaline extraction, differentiate, humic acid, organic carbon.

\section{Introduction}

Biochar is produced by burning organic matter such as wood and grass residues, sugar cane residues or manure under low oxygen concentrations
Received September 28, 2012. Accepted June 5, 2013. Corresponding author: nlarah@uta.cl in a process known as pyrolysis (Leinweber and Schulten, 1999). Despite its aromatic chemical structure, biochar can be oxidized by biotic and abiotic processes, in which negatively charged functional groups (carboxylic, phenolic, hydroxyl, carbonyl, carbon in quinone form, etc.) are formed on biochar surfaces (Singh et al., 2010). This process yields a material with a high cation exchange capacity, which may contribute 
to soil fertility. These functional groups also have alkaline characteristics, thereby reducing soil acidity (Brewer et al., 2011).

The majority of biochar is considered biologically inert due to its degree of oxidation and its strong resistance to decomposition, which allow it to remain in the soil as a carbon (C) sink. Among the classifications of soil organic matter, the simplest divides soil organic matter into "live" and "not live" (Labrado, 2001). These organic substances are composed of polymerized compounds of high molecular weight; they have colloidal properties, a high cation exchange capacity, and are resistant to biodegradation (Fuentes, 1999). Although the structure of these substances has not been defined, they are hypothesized to be formed by complex macromolecular groupings whose fundamental units are phenolic aromatic compounds such as lignin (Chiaa et al., 2010). These groupings contain large amounts of acidic functional groups, which lead to the formation of salts and less condensed chemical structures in basic solutions. These products (except for humic substances) are prone to hydrolysis. Humic substances, due to their greater levels of condensation, are only soluble in hot sodium hydroxide (Fassbender, 1994).

Many methods have been proposed for the determination of organic $\mathrm{C}$ in biochar-amended soils, including the measurement of extractible organic compounds such as benzene polycarboxylic acids (Brodowski et al., 2005) or other biomarkers (Elias et al., 2001), chemical oxidation at $375{ }^{\circ} \mathrm{C}$ followed by elemental analysis of the residue (Gélinas et al., 2001; Gustafsson et al., 2001), oxidation with dichromic acid (Song et al., 2002) or sodium hypochlorite followed by elemental analysis of the residues using ${ }^{13} \mathrm{C}$-NMR (Simpson and Hatcher, 2004), thermal/optic laser transmittance or reflectance (Huang et al., 2006), ultraviolet photo-oxidation of the sample followed by ${ }^{13} \mathrm{C}-\mathrm{NMR}$ analysis of the residue (Skjemstad et al., 1999), and thermogravimetric analysis of the sample under a flow of $\mathrm{He}_{80} \mathrm{O}_{20}$ (López-Capel et al., 2005; Manning and Lopez-Capel, 2009).
Almost all these methods are limited by the possible interference of other materials present in the biochar and soils; for example, clays and carbonates are known to influence the weight loss of samples (Hammes et al., 2007).

The most widely used method for quantifying soil total organic carbon (TOC) is the Walkley-Black method (Walkley and Black, 1934), which consists of the wet combustion of the organic matter using a mixture of dichromate and sulfuric acid. After the reaction, the amount of reduced chromium is measured colorimetrically (Soon and Abboud, 1991). However, both resident soil organic carbon (OC) and biochar react to this procedure, making it unable to discriminate between the $\mathrm{C}$ sources in biochar-amended soil. An alternative method for discriminating $\mathrm{C}$ sources in these soils must therefore be developed.

A suitable method for quantifying the TOC and biochar in soils should be practical and produce results comparable to those obtained using techniques based on thermal differentiation and quantification with an elemental analyzer. In the present study, the extraction, quantification and differentiation of TOC and biochar OC was evaluated in soils both amended and not amended with humic acids.

\section{Materials and methods}

\section{Samples}

Samples of two arid soils were used in this study, both of which were taken from agricultural areas surrounding the city of Arica, XV region of Chile. The area is an arid region with a mean annual precipitation of less than $0.4 \mathrm{~mm}$; the soils are characterized by high salinity and an electrical conductivity (EC) of above $20 \mathrm{dS} \mathrm{m}^{-1}$ (Espina, 1971). The physical and chemical characteristics of these soils are known to include low organic matter content $(<3 \%)$, high porosity and low bulk density (INDERCO, 1980; INGENDESA, 1993, 
1995; Kosmas and Moustakas, 1990). Samples were taken from the $0-20 \mathrm{~cm}$ upper soil layer. The first sample was taken from a tomato field in the Azapa Valley, km 12 in the Alto Ramirez sector. The second sample was taken from a maize field in the Lluta Valley, km 10 of the same sector. Both of the samples were a composite of 4 sub-samples taken randomly over an area of 100 $\mathrm{m}^{2}$. Large residues were removed from the soil, and the subsamples were mixed to obtain a final sample of $2 \mathrm{~kg}$.

Solutions. All of the aqueous solutions were prepared using distilled water with an electrical conductivity $<5 \mu \mathrm{S} \mathrm{cm}^{-1}$. The preparations of the solutions are as follow: alkaline extracting solution (sodium hydroxide $1 \mathrm{~mol} \mathrm{~L}^{-1}$ and sodium hexametaphosphate $4 \% \mathrm{w} / \mathrm{v}$ ), sodium dichromate $\left(0.5 \mathrm{~mol} \mathrm{~L}^{-1}\right)$, sulfuric acid $(2 \mathrm{~mol}$ $\left.\mathrm{L}^{-1}\right)$, sodium standard $\left(1,000 \mathrm{mg} \mathrm{L}^{-1}\right)$, potassium chloride $\left(0.1000 \mathrm{~mol} \mathrm{~L}^{-1}\right)$, silver nitrate $(0.0983$ mol L-1), potassium chromate $(5 \% \mathrm{w} / \mathrm{w})$, potassium bromide (p.a. Merck), dispersing solution (sodium hexametaphosphate $4 \% \mathrm{w} / \mathrm{v}$ with sodium carbonate $1 \% \mathrm{w} / \mathrm{v})$.

Instrumentation. The following instruments were used in the study: a molecular absorption spectrophotometer (UV-VIS Genesys 6), orbital shaker (Heidolph Unimax 2010), forced flow oven (Hiender), $\mathrm{pH} / \mathrm{mV}$ meter (Denver Instrument UB-10), conductivity meter (WTW Cond 330i/ SET), VACUUBRAND vacuum pump (MembranVakuumpumpe MZ2C $1.7 \mathrm{~m}^{3} \mathrm{~h}^{-1}$ ), flame photometer (JENWAY PFP7), elemental analyzer (Fisons EA 1108), and a Spectrum 100 Fourier transform (FTIR) infrared spectrometer (Perkin-Elmer).

\section{Treatment and characterization of soils and biochar}

The soil samples were cleaned, homogenized, and air dried in the shade for $24 \mathrm{~h}$, then passed through a $2 \mathrm{~mm}$ sieve. This fraction was used for the physiochemical characterization of the soil.
A portion of the soil was further sieved to 0.25 $\mathrm{mm}$, and this fraction was used to determine the TOC of the soil using the modified Walkley-Black method (Figueroa, 1987).

The biochar used in this study was obtained from the provider "Bricapar S.A." Paraguay, and it was reportedly made from $100 \%$ hardwood. The biochar was ground with a porcelain mortar and pestle to particles that passed through a $0.25 \mathrm{~mm}$ sieve. The soil samples were mixed with known amounts of biochar (OC of $21.90 \% \mathrm{w} / \mathrm{w}$ ) and humic extracts (OC of $15.51 \% \mathrm{w} / \mathrm{w})(2.00 \mathrm{~g}$ total soil; $0.040 \mathrm{~g}$ biochar; $0.200 \mathrm{~g}$ humic extract and $1.50 \mathrm{~g}$ humidified soil) to increase artificially the total organic carbon $(\mathrm{TOC}=\mathrm{OC}$ of soil $+\mathrm{OC}$ of humus) content. To obtain a more homogeneous mixture of the soil and humic acids, a moist paste was made from the soil, humic acid extract and water, and this paste was air dried for $24 \mathrm{~h}$ in the shade. A number of these amended samples were used to determine the best method of $\mathrm{C}$ extraction, and the remaining samples were used to produce the extracts for the differentiation of TOC and OC from biochar (with 10 replicates). In the saturated extract of each soil sample, the following parameters were analyzed: $\mathrm{pH}$ in water (soil: solution ratio, 1:2.5), electrical conductivity, sodium content by flame photometry, chloride content using Mohr's method and texture using the Bouyoucos method (Bouyoucos, 1962).

The amount of distilled water required to form a saturated paste with a known amount of soil was recorded, and the results are expressed in $\mathrm{mL}$ of water per $100 \mathrm{~g}$ soil. The carbon, nitrogen and ash contents of the soil were analyzed using an elemental analyzer at the Laboratorio de Recursos Renovables de la Universidad de Concepción.

The soil, biochar, and mixtures of the soil with the humic acid extracts and the humidified soil with biochar were extracted using an alkaline solution and hot water to quantify the TOC in the solid phase before extraction and in the extracted liquid phase. A mass balance was established between 
the $\mathrm{OC}$ in the humidified soil and the $\mathrm{OC}$ from the biochar in the soil.

\section{Extraction and determination of TOC in alkaline solution from the various substrates}

Extraction. Two extraction procedures were tested. The first method was conducted at room temperature $\left(20^{\circ} \mathrm{C}\right)$, and the second was conducted under applied heat in a reflux system. For each dried humidified soil sample (soil mixture and humic acids), two sets of triplicate samples of $3.00 \mathrm{~g}$ were weighed. Triplicate samples of 5.00 $\mathrm{g}$ biochar were also weighed, and mixtures of the humidified soil and biochar were prepared in equal proportions by weight to establish a 1:1 ratio of both components. These materials were then treated with concentrated sulfuric acid $(95-97 \% \mathrm{w} / \mathrm{w})$ and maintained at $65^{\circ} \mathrm{C}$ for 10 min to eliminate any chlorides or carbonates. Fifty $\mathrm{mL}$ of an alkaline extractant solution (sodium hydroxide at $1 \mathrm{~mol} \mathrm{~L}^{-1}$ and sodium hexametaphosphate at $4 \% \mathrm{w} / \mathrm{v}$ ) were added to the humidified soil samples, while $75 \mathrm{~mL}$ were added to the biochar and biochar-humidified soils. For the first set of samples, the extraction was conducted at room temperature for $1 \mathrm{~h}$. The second set of samples were brought to a boil in a Soxhlet reflux apparatus for $1 \mathrm{~h}$ and left to cool for $15 \mathrm{~min}$. The samples were then centrifuged in polypropylene tubes at 2,500 rpm for $10 \mathrm{~min}$. The supernatant was collected, and the solid residue from each sample then washed with 10 $\mathrm{mL}$ of cold extractant solution and centrifuged again for $10 \mathrm{~min}$. The resulting supernatant was collected in a volumetric flask. Each tube was washed 5 times, with the final supernatant being colorless or slightly yellow. The presence of this clear supernatant was established as the end point of the extraction process.

Determination. From each volumetric flask of alkaline extract, triplicate $50 \mathrm{~mL}$ samples were taken. The solution was neutralized with $2 \mathrm{~mol}$ $\mathrm{L}^{-1}$ sulfuric acid. The humidified soil samples required $9.4 \mathrm{~mL}$ of acid, while the samples of the humidified soil-biochar mixture required $10.9 \mathrm{~mL}$. The extracts were vacuum-filtered through a fiberglass membrane with a pore size of $1.6 \mu \mathrm{m}$ to obtain solutions that were free from suspended particles. The solid extraction residues were dried at $85-90{ }^{\circ} \mathrm{C}$, and the $\mathrm{OC}$ of each sample was then quantified using the modified Walkley-Black method (Figueroa, 1987). Ten $\mathrm{mL}$ of sodium dichromate $\left(0.5 \mathrm{~mol} \mathrm{~L}^{-1}\right)$ were then added, which reacted with the organic matter to form $\mathrm{CO}_{2}$ and chromophore $\mathrm{Cr}$ (III) in a stoichiometric fashion. The latter product was quantified using a UV-VIS molecular absorption spectrophotometer at $600 \mathrm{~nm}$ (Jackson, 1970). To compare the results, the TOC was analyzed using an elemental analyzer for one biochar sample and one sample of humidified soil from the Azapa Valley.

Determination of TOC in the solid residue from the alkaline extraction. The solid residue samples were quantitatively transferred from the centrifuge tubes into Erlenmeyer flasks and dried between $85-90{ }^{\circ} \mathrm{C}$. Subsamples of between 40 and $70 \mathrm{mg}$ were taken from each residue sample to determine their OC contents using the Walkley-Black method.

\section{Extraction and quantification of the TOC soluble in hot water in humidified soil samples}

Five grams of each sample were weighed in triplicate, and the same methodology as described above was applied, replacing the alkaline extractant with distilled water in the reflux system and subsequent washings. The OC contents were quantified using the Walkley-Black method.

\section{Biochar characterization by infra-red spectroscopy (Purevsuren et al., 2003)}

Biochar pellets were made with $\mathrm{KBr}$ using a manual pelletizer. The samples were analyzed by Fourier transform infra-red spectroscopy (FTIR). 


\section{Results and discussion}

\section{Characterization of soils and biochar}

The soils used in this experiment were representative of typical arid soils and were low in organic matter; despite the presence of salts in the soil samples, their $\mathrm{pH}$ values were nearly neutral (7.53-7.71). The soils were also of different USDA textural classes (Soil Survey Staff, 2010); the soil from the Azapa Valley had a low clay content (Table 1).

Table 2 describes the main peaks that characterize the functional groups in the biochar, which are in agreement with those reported for biochar from casein (Purevsuren et al., 2003). This analysis confirms that biochar has a defined and very stable structure. The elemental analysis of the biochar indicates that it contained a $\mathrm{C}$ content of $79.2 \pm$ $0.04 \%$, an $\mathrm{H}$ content of $3.3 \pm 0.12 \%$ and $2.6 \%$ ash.

\section{Amounts of TOC from soil, humic acid, biochar and humidified soils}

Table 3 shows the percentages of TOC extracted from the humidified Azapa and Lluta soils. When the percentage of OC obtained using alkaline extraction under reflux for the humidified Azapa soil $(2.21 \pm 0.09 \%)$ is compared to the amount of $\mathrm{C}$ from the elemental analysis of the same sample $(2.3 \pm 1 \%)$, the percent recovery can be calculated at $96.1 \%$. This result is in agreement with the fact that in soil, C exists in inorganic forms as well as organic forms from soil organic matter (SOM) and other, less condensed species. Furthermore, the soil contains carbonization residues from the burning of crop residues, which are neither quantifiable using the Walkley-Black method nor extractible using the proposed method (Matus, et al., 1997).

The yields for the extractions conducted at room temperature ranged from 63.87 - 69.68, while those for the reflux extraction ranged from 77.9781.45. Reflux extraction is also more efficient, as extraction at room temperature requires twice as many washes to reach the point at which the extractant has a light yellow color.

The biochar had $21.90 \%$ TOC w/w, with $20.68 \%$ OC $\mathrm{w} / \mathrm{w}$ remaining in the solid fraction after alkaline extraction under reflux. This result represents an extractible fraction of approximately $5 \%$, demonstrating that the biochar OC does not produce any significant interference in this method. The extracted fraction corresponds to the organic carbon from the functional groups found on the active surfaces of the biochar.

To demonstrate the efficiency of the extractant solution, the amount of $\mathrm{OC}$ in the humidified soils

Table 2. Functional groups of the biochar samples according to FTIR spectra.

\begin{tabular}{lc}
\hline Functional group absorbance & $v\left(\mathrm{~cm}^{-1}\right)$ \\
\hline O-H & $3400-3500$ \\
C-H (aliphatic) & $2850-2922$ \\
C=O & $1610-1632$ \\
C-C (aromatic) & 1385 \\
C-O-C (etheric) & $1115-1130$ \\
C-H (aromatic) & $615-620$ \\
\hline
\end{tabular}

Table 1. Characterization of the soils.

\begin{tabular}{|c|c|c|}
\hline Parameter & Azapa soil & Lluta soil \\
\hline $\mathrm{pH}$ & 7.71 & 7.53 \\
\hline Electrical conductivity $\left(\mathrm{dS} \mathrm{m}^{-1}\right)$ at $25^{\circ} \mathrm{C}$ & 73.73 & 37.64 \\
\hline Sodium $(\mathrm{mM})$ & $577.50 \pm 3.96$ & $176.41 \pm 1.83$ \\
\hline Chloride (mM) & $398.15 \pm 2.73$ & $198.45 \pm 2.06$ \\
\hline Texture at $20^{\circ} \mathrm{C}\left(\mathrm{g} \mathrm{kg}^{-1}\right)$ & 772 sand; 34 clay; 194 silt & 612 sand; 114 clay; 274 silt \\
\hline Organic matter $\left(\mathrm{g} \mathrm{kg}^{-1}\right)$ & $10.3 \pm 0.3$ & $16.9 \pm 0.3$ \\
\hline USDA textural class & Loamy sand & Sandy loam \\
\hline Soil water saturation $\left(\mathrm{mL} 100 \mathrm{~g}^{-1}\right)$ & 20.6 & 52.8 \\
\hline Organic carbon $\left(\mathrm{g} \mathrm{kg}^{-1}\right)$ & $8.9 \pm 0.5$ & $12.6 \pm 0.8$ \\
\hline
\end{tabular}


that was soluble in boiling water was determined. For the humidified Lluta soil, this value was $41.41 \%$, while for the humidified Azapa soil, the value was $57.75 \%$ (Table 3 ). An inverse relationship was observed between the clay content in the soil (Table 1) and the amount of OC extracted using alkaline extraction. For example, the extraction percentage under reflux was $3.5 \%$ less in the Lluta soil than in the Azapa soil (Table 3). The amount of soil OC soluble in hot water for the Lluta sample was considerably (16.3\%) lower than for the Azapa soil. When the humidified Lluta soil was extracted with alkaline solution in the reflux system, $1.12 \pm 0.03 \%$ of OC was extracted, while the theoretically maximum extractible amount is $1.39 \%$. The difference between these two values is $19.62 \%$. For the humidified Azapa soil, the extracted amount represents $1.15 \pm 0.03 \%$, while the theoretically maximum extractible amount is $1.38 \%$. The difference in this case is $15.87 \%$.

The mass balances for the humidified soils and biochar exposed to the alkaline extractant under reflux showed a negative error $3.62 \%$ for the humidified Azapa soil, 5.73\% for the humidified Lluta soil and $1.14 \%$ for the biochar, see Table 4 ) due to mass loss during the procedure. However, these values are acceptable, as the proposed extraction technique is still in the evaluation phase. The precision and accuracy of the method may be better controlled by changing certain aspects of the process. For example, when the alkaline OC extracts were dried on a hot plate, irregularly shaped agglomerates were formed. These were composed mainly of salts, which encapsulated some organic matter. Even when exposed to exothermic extraction with dichromic acid (Walkley Black method), these salts were not fully dissolved, and some organic matter was protected from oxidation.

Alkaline extraction at boiling temperature and reflux yielded the greatest amounts of organic carbon extracted of the humic acid of the soil, additional humic matter and the biochar.

The percentages of extracted organic carbon are very similar to the total organic carbon values for the soil, indicating that the organic carbon obtained from the extraction corresponds mostly to that present in the soil as opposed to that originating from biochar. Biochar carbon is much more difficult to extract due to its chemical properties and very stable structure.

In a field situation, the amount of biochar added to the soil would be considerably less than that used in this study, as the contribution of biochar to $\mathrm{OC}$ is $<6 \%$. The amount of organic carbon extracted represents between $78 \%$ and $81 \%$ of the total organic carbon. Therefore, this alternative method for the differentiation

Table 3. Total organic carbon (TOC) extracted using the modified Walkley-Black method, OC extracted under alkaline conditions at $20^{\circ} \mathrm{C}$ and under reflux, and $\mathrm{OC}$ extracted with boiling water in mixtures of humidified Azapa soil and humidified Lluta soil, all quantified using the Walkley-Black method.

\begin{tabular}{lcc}
\hline Extraction & $\begin{array}{c}\text { Humidified Azapa soil } \\
(\% \mathrm{w} / \mathrm{w})\end{array}$ & $\begin{array}{c}\text { Humidified Lluta soil } \\
(\% \mathrm{w} / \mathrm{w})\end{array}$ \\
\hline Under alkaline conditions at $20^{\circ} \mathrm{C}$ & $2.21 \pm 0.09$ & $2.27 \pm 0.09$ \\
TOC & $1.54 \pm 0.05$ & $1.45 \pm 0.06$ \\
OC Extracted & 69.68 & 63.87 \\
Extraction & & \\
Under alkaline conditions and reflux & $2.21 \pm 0.09$ & $2.27 \pm 0.09$ \\
TOC & $1.80 \pm 0.06$ & $1.77 \pm 0.1$ \\
OC Extracted & 81.45 & 77.97 \\
Extraction & & $2.27 \pm 0.09$ \\
With boiling water & $2.21 \pm 0.09$ & $0.94 \pm 0.21$ \\
TOC & $1.21 \pm 0.05$ & 41.41 \\
OC Extracted & 57.75 & \\
Extraction & & \\
\hline
\end{tabular}


Table 4. Determination of OC $(\% \mathrm{w} / \mathrm{w})$ by alkaline extraction under reflux

\begin{tabular}{lccc}
\hline & $\begin{array}{c}\text { OC extracted }+ \\
\text { OC not extracted }\end{array}$ & TOC & \% error \\
\hline Biochar & 21.65 & $21.90 \pm 0.06$ & 1.14 \\
$\begin{array}{l}\text { Humidified } \\
\text { Azapa soil }\end{array}$ & 2.13 & $2.21 \pm 0.09$ & 3.62 \\
$\begin{array}{l}\text { Humidified } \\
\text { Lluta soil }\end{array}$ & 2.14 & $2.27 \pm 0.09$ & 5.73 \\
\hline
\end{tabular}

of carbon sources produces results which are comparable to those of other techniques and may be performed using local resources.

\section{Acknowledgments}

The authors are grateful the project UTA- Mayor 4742-13 and the Convenio de Desempeño Universidad de Tarapacá - Mineduc.

\section{Resumen}

N. Lara, L. Figueroa, F. Carvajal, Y. Zapata, C. Urbina y H. Escobar. 2013. Diferenciación cuantitativa entre el carbono orgánico del suelo y el carbono del biochar en suelos áridos. Cien. Inv. Agr. 40(2): 387-395. Con el fin de conocer y asimilar el efecto del biochar, su presencia y estabilidad, es necesario diferenciar entre las dos fuentes principales de carbono, que corresponden a la materia orgánica del suelo y al carbono orgánico del biochar adicionado. El método aplicado es la extracción sólido-líquido con una solución alcalina, mejorando la eficiencia en un sistema de reflujo y cuantificado por el método modificado de Walkley and Black, en muestras de suelos áridos aledaños a la ciudad de Arica, XV región de Chile, con una media anual de precipitaciones inferior a $0,4 \mathrm{~mm}$. Los suelos se caracterizan por tener una alta salinidad, bajo contenido de materia orgánica, alta porosidad y baja densidad aparente. Los porcentajes de carbono orgánico total extraído son muy similares a los valores de carbono de origen orgánico del suelo, lo que evidencia que esta técnica extrae principalmente el carbono orgánico del suelo y no el carbono procedente del biochar. En efecto, el carbono del biochar representa menos del $6 \%$ del carbono orgánico extraído por este método. Los resultados demuestran que esta metodología puede diferenciar cuantitativamente entre el carbono orgánico del suelo y el carbono orgánico procedente del biochar aplicado. Por lo tanto el método representa una valiosa alternativa a la utilización de un analizador elemental.

Palabras clave: Ácidos húmicos, carbono orgánico, diferenciación, extracción alcalina.

\section{References}

Bouyoucos, G. J. 1962. Hydrometer method improved for making particle size analyses of soils. Agron. J., 54:464-465.

Brewer, C., R. Unger, K. Schmidt-Rohr, and R. Brown, R. 2011. Criteria to select biochars for field studies based on biochar chemical properties. Bioenerg. Res. 4:312-323.
Brodowski, S., A. Rodionov, L. Haumaier, B. Glaser, and W. Amelung. 2005. Revised black carbon assessment using benzene polycarboxylic acids. Organic Geochem. 36:1299-1310.

Chiaa, Ch., P. Munroe, Y. Lina, and S. Joseph. 2010. Microscopic characterisation of synthetic Terra Preta. Australian J. of Soil Res. 48(6-7):593-605.

Elias, V. O., B.R.T. Simoneit, R.C. Cordeiro, and B. Turcq. 2001. Evaluating levoglucosan as an indi- 
cator of biomass burning in Carajás, Amazônia: A comparison to the charcoal record. Geochim. et Cosmochim. Acta 65:267-272.

Espina, L. 1971. Estudio agroeconómico del valle de Azapa. U. de Chile. Facultad de Agronomía. Departamento de Ciencias Económicas y Sociales. $155 \mathrm{pp}$.

Fassbender, H.W. 1994. Química de suelos con énfasis en suelos de América Latina. $2^{\text {nd }}$ ed., San José, CR: Instituto Interamericano de Ciencias Agrícolas de la O.E.A. 420 pp.

Figueroa, L. 1987. Alternativa de sustitución para la eliminación de interferente cloruro en la determinación de materia orgánica de suelos áridos, según el método Walkley y Black. Agricultura Técnica 47:431-432.

Fuentes, J.L. 1999. El suelo y los fertilizantes. $5^{\text {th }}$ ed., Madrid: Ediciones Mundi-Prensa Libros, S.A. $160 \mathrm{pp}$.

Gélinas,Y., K.M. Prentice, J.A. Baldock, and J.I. Hedges. 2001. An improved thermal oxidation method for the quantification of soot/graphitic black carbon in sediments and soils. Environm. Sci. and Techn. 35:3519-3525.

Gustafsson, Ö., T.D. Bucheli, Z. Kukulska, M. Andersson, C. Largeau, J. Rouzaud, C. Reddy, and T. Eglinton. 2001. Evaluation of a protocol for the quantification of black carbon in sediments. Global Biogeochem. Cycles 15:881-890.

Hammes, K., M.W. Schmidt, R.J. Smernik, A. Lloyd, W. Currie, H. Nguyen, P. Louchouarn, S. Houel, Ö. Gustafsson,M. Elmquist, G. Cornelissen, J. Skjemstad, C. Masiello, J. Song, P. Peng, S. Mitra, J. Dunn, P. Hatcher, W. Hockaday, D. Smith, C. Hartkopf-Fröder, A. Böhmer, B. Lüer, B. Huebert, W. Amelung, S. Brodowski, L. Huang, W. Zhang, P. Gschwend,D. Flores-Cervantes, C. Largeau, C. Rumpel, G. Guggenberger, K. Kaiser, A. Rodionov, F. Gonzalez-Vila, J. Gonzalez-Perez, J. De La Rosa, D. Manning, E. López-Capél, and L. Ding. 2007. Comparison of quantification methods to measure fire-derived (black/elemental) carbon in soils and sediments using reference materials from soil, water, sediment and the atmosphere. Global Biogeochem. Cycles, 21, GB3016. 18 pp.
Huang, L,.J. Brook, W. Zhang, S. Li, L. Graham, D. Ernst, A. Chivulescu, and G. Lu. 2006. Stable isotope measurements of carbon fractions (OC/ EC) in airborne particulate: A new dimension for source characterization and apportionment. Atm. Environm. 40:2690-2705.

INGENDESA. 1993. Consultoría Dep-012, Análisis de descontaminación y embalse en río Lluta". INGENDESA (Empresa de Ingeniería de Endesa). Vol. 4/4- Dirección de Riego. Ministerio de Obras Públicas. 111 pp.

INGENDESA. 1995. Consultoría Dep-012, Análisis de descontaminación y embalse en río Lluta. INGENDESA (Empresa de Ingeniería de Endesa). II Parte - Drenaje. Informe Ejecutivo. Dirección de riego. Ministerio de Obras Públicas. 45 pp.

INDERCO, LTDA. 1980. Estudio de la red de drenaje del valle del río Lluta. INDERCO, LTDA. (Ingenieros de suelos). Dirección General de Aguas. Ministerio de Obras Públicas. 125 pp.

Jackson, M. L. 1970. Análisis químico de suelos. $2^{\text {nd }}$ ed. Edi. Omega. Barcelona, España. 662 pp.

Kosmas, C., and N. Moustakas. 1990. Hydraulic conductivity and leaching of an organic saline-sodic soil. Geoderma 46:363-370.

Labrado, J. 2001. La materia química en los agrosistemas. Aproximación al conocimiento de la dinámica, la gestión y la reutilización de la materia orgánica en los agrosistemas. $2^{\text {nd }}$ ed. Editorial Mundi-Prensa Libros S.A. Barcelona, España. 297 pp.

Leinweber, P., and H-R. Schulten. 1999. Advances in analytical pyrolysis of soil organic matter. J. Anal. Appl. Pyrolysis 49:359 -383.

Lopez-Capel, E., S.P. Sohi, J.L. Gaunt, and D.A.C. Manning. 2005. Use of thermogravimetry- differential scanning calorimetry to characterize modelable soil organic matter fractions. Soil Science Society of Am. J. 69:136-140.

Matus, F. J., A. Hermosilla, C. Maire, and S. Ortega. 1997. Comparación en la determinación de materia orgánica por oxidación parcial y completa en diversos suelos de la VII región. Agricultura Técnica (Chile) 57:195-199.

Manning, D. A. C., and E. Lopez-Capel. 2009. Test procedures for determining the quantity of bio- 
char within soils. In: Lehmann, J. and S. Joseph (ed.). Biochar for environmental management. Editorial London - Sterling, VA. p. 301-315.

Purevsuren, B., B. Avid, B. Tesche, and Y.A. Davaajav. 2003. A Biochar from casein and its properties. J. Mat. Soc. 38:2347-2351.

Singh, B., B.P. Singh, and A.L. Cowie. 2010. Characterisation and evaluation of biochars for their application as a soil amendment. Australian J. Soil Res. 48:516-525.

Simpson, M. J., and P.G. Hatcher. 2004. Determination of black carbon in natural organic matter by chemical oxidation and solid-state ${ }^{13} \mathrm{C}$ nuclear magnetic resonance spectroscopy. Org. Geochemistry 356:923-935.

Skjemstad, J.O.,J.A. Taylor, and R.J. Smernik. 1999. Estimation of charcoal (char) in soils.
Comm. in Soil Sci. and Plant Anal. 30:22832298.

Soil Survey Staff. 2010. Keys to soil taxonomy, 11th ed. p. 33. USDA-Natural Resources Conservation Service, Washington, DC, USA.

Song, J., P. Peng, and W. Huang. 2002. Black carbon and kerogen in soils and sediments. 1. Quantification and characterization. Environm. Sci. and Techn. 36:3960-3967.

Soon, Y. K., and S.A. Abboud. 1991. Comparison of some methods for soil organic - carbon determination. Comm. in Soil Sci. and Plant Anal. 22:943-954.

Walkley, A., and I.A. Black. 1934. An examination of the Degtjareff method for determining soil organic matter, and proposed modification of the chromic acid titration method. Soil Sci. 37:29- 38 . 
